\title{
RELATIONSHIP BETWEEN PARAMETERS OF THE LUMBAR FACET JOINTS IN A LONG-TERM POSTOPERATIVE OUTCOME
}

\author{
RELAÇÃO ENTRE PARÂMETROS DAS LIGAÇÕES DA FACETA LOMBAR EM UM RESULTADO \\ PÓS-OPERATÓRIO DE LONGO PRAZO
}

\author{
RELACIÓN ENTRE PARÁMETROS DE LAS ARTICULACIONES FACETARIAS LUMBARES \\ EN RESULTADO POSTOPERATORIO A LARGO PLAZO
} \author{
IgOR VADIMOVICH BASANKIN ${ }^{5}$ \\ 1. Irkutsk State Medical University, Irkutsk, Russia. \\ 2. Railway Clinical Hospital, Irkutsk, Russia. \\ 3. Irkutsk Research Center Surgery and Traumatology, Irkutsk, Russia. \\ 4. Irkutsk state medical academy of postgraduate education, Irkutsk, Russia. \\ 5. Research Institute Krasnodar Regional Hospital 1, Krasnodar, Russia.
}

Vadim Anatol'Evich Bryaltsev $1,2,3,4$, Andrel Andreevich Kalinin ${ }^{1,2}$, Alyona Konstantinovna Okoneshnikova ${ }^{1,2}$, Yuri Yakovlevich Pestryakov',

\begin{abstract}
Objective: To analyze the impact of the relationship between tropism and angulation of the lower lumbar facet joints on a remote clinical outcome after dynamic and rigid surgical interventions. Methods: Patients with degenerative diseases of the lower lumbar spine were subdivided into three groups, according to the method of surgical treatment: 1$)(n=48)$ the use of an artificial prosthesis intervertebral disc (IVD); 2) ( $n=42$ ) the use of interbody fusion combined with transpedicular and transfacet stabilization; 3$)(n=51)$ the use of interbody fusion and bilateral transpedicular stabilization. Analysis was performed of the remote clinical parameters and neuroimaging characteristics before the operation was performed. Results: When analyzing clinical and instrumental parameters, a significant correlation was found between the long-term outcomes of surgical treatment on the VAS and Oswestry scales and the neuroimaging data on angulation and tropism of the facet joints (FJ). Conclusions: The data obtained testify to the importance of preoperative diagnosis of tropism and angulation of the lower lumbar facet joint, which enables differentiated surgical tactics to be selected, and remote clinical outcomes to be optimized. In the presence of neuroimaging parameters of Facet Joint angulation of less than $60^{\circ}$, regardless of the presence of tropism, it is possible to perform total arthroplasty of IVD. When neuroimaging parameters of Facet Joint angulation of more than $60^{\circ}$ are detected, rigid stabilization of the operated segment is recommended, while in the absence of tropism of Facet Joints, a contralateral transfacetal fixation is possible; in the presence of tropism, it is expedient to perform bilateral transpedicular stabilization. Level of Evidence II; Prognostic StudiesInvestigating the Effect of a Patient Characteristic on the Outcome of Disease.
\end{abstract}

Keywords: Spine; Chronic disease; Zygapophyseal joint; Spinal fusion; Arthroplasty.

RESUMO

Objetivo: Analisar o impacto da relação entre tropismo e angulação das articulações lombares inferiores em um resultado clínico remoto, após intervenções cirúrgicas dinâmicas e rígidas. Métodos: Dependendo do método de tratamento cirúrgico, os pacientes com doenças degenerativas da coluna vertebral lombar inferior foram subdivididos em três grupos: 1) ( $n=48)$ com a utilização de uma prótese de disco intervertebral artificial (IVD); 2) ( $n=42)$ com utilização de fusão intercorporal, combinado com transpedicular e estabilização transfacetal; 3) $(n=51)$ com a utilização de fusão intercorporal e estabilização transpedicular bilateral. A análise dos parâmetros clínicos remotas e características de neuroimagem antes da operação foi realizada. Resultados: Quanto a análise de parâmetros clínicos e instrumentais, uma correlação significativa foi encontrada entre os resultados a longo prazo do tratamento cirúrgico com as escalas VAS e Oswestry com dados de neuroimagiologia sobre angulação e tropismo de articulações (FJ). Conclusão: Os dados obtidos atestam a importância do diagnóstico pré-operatório de tropismo e angulação da articulação faceta lombar inferior, que permite escolher táticas cirúrgicas diferenciadas e otimizar os resultados clínicos remotos. Na presença de parâmetros de neuroimagiologia de angulação de FJs menor do que 600, independentemente da presença de tropismo, é possível realizar a artroplastia total da IVD. Quando a detecção de parâmetros de neuroimagens FJ, angulação mais do que 600, a estabilização rígida do segmento operado é recomendado, enquanto que na ausência do tropismo de FJs, uma fixação transfacetal contralateral é possível; na presença de tropismo, é conveniente realizar a estabilização transpedicular bilateral. Nível de Evidência II; Estudos prognósticos - Investigação do efeito de característica de um paciente sobre o desfecho da doença.

Descritores: Coluna vertebral; Doença crônica; Articulação zigapofisária; Fusão Vertebral; Artroplastia.

\section{RESUMEN}

Objetivo: Analizar el impacto de la relación entre el tropismo y la angulación de las articulaciones facetarias lumbares inferiores en un resultado clínico remoto después de intenenciones quirúrgicas dinámicas y rígidas. Métodos: Los pacientes con enfermedades degenerativas de la columna lumbar inferior se subdividieron en tres grupos de acuerdo con el método de tratamiento quirúrgico: 1) ( $n=48)$ uso de una prótesis artificial de disco intervertebral (D/V); 2) ( $n=42)$ uso de la fusión intersomática combinada con la estabilización transpedicular y transfacetaria; 3) ( $n=51)$ fusión 
intersomática y estabilización transpedicular bilateral. Se realizó el análisis de los parámetros clínicos remotos y las características de neuroimagen antes de que se realizara la operación. Resultados: Al analizar los parámetros clínicos e instrumentales, se encontró una correlación significativa entre los resultados a largo plazo del tratamiento quirúrgico en las escalas EVA y Oswestry con datos de neuroimagen sobre la angulación y el tropismo de las articulaciones facetarias (AF). Conclusiones: Los datos obtenidos confirman la importancia del diagnóstico preoperatorio de tropismo y la angulación de la articulación facetaria lumbar inferior, lo que permite elegir tácticas quirúrgicas diferenciadas y optimizar los resultados clínicos remotos. En presencia de parámetros de neuroimagen de angulación de AF inferior a $60^{\circ}$, independientemente de la presencia de tropismo, es posible realizar una artroplastia total de DIV. Al detectar los parámetros de neuroimagen de la angulación de la articulación facetaria de más de $60^{\circ}$, se recomienda la estabilización rígida del segmento operado, mientras que en ausencia de tropismo de las articulaciones facetarias es posible una fijación transfacetaria contralateral; en presencia de tropismo, es conveniente realizar una estabilización transpedicular bilateral. Nivel de evidencia II; Estudios pronósticos - Investigación del efecto de una característica del paciente sobre el desenlace de la enfermedad.

Descriptores: Columna vertebral; Enfermedad crónica; Articulación Cigapofisaria; Fusión vertebral; Artroplastia.

\section{INTRODUCTION}

Rigid stabilization is currently the gold standard for the treatment of most degenerative diseases of the lumbar spine..$^{1-3}$ However, there are still a significant number of unsatisfactory clinical postoperative results associated with the progression of the degenerative process in the operated and adjacent segments due to biomechanical disorders. ${ }^{2-4}$

It has been proven that degeneration of the adjacent level occurs as a result of increased load on the facet joints and intervertebral discs, which is associated with the development of pathological mobility of the vertebral-motor segment (VMS) above the level of the rigid stabilization. ${ }^{1,2}$

Potential predisposing factors contributing to accelerated degeneration of the adjacent level are: degenerative changes in the joints of FJs, the type and extent of fusion, changes in the configuration of the spinal column in the sagittal plane, and previous surgical manipulations in the adjacent segment. ${ }^{1,4}$

Brailsford JF in 1928 first used the term "FJ tropism" to denote an asymmetry between the right and left FJs, or the presence of a more sagittal orientation of one of the FJs. ${ }^{5}$ Masharawi et al. demonstrated that tropism of the FJs in the thoracic spine is one of the norm variants. ${ }^{6}$ The presence of tropism of FJs in the lumbosacral spine is the cause of degenerative diseases. ${ }^{7-9}$

To select the right tactics for surgical treatment of patients with degenerative diseases of FJs, it is necessary to determine and justify the optimal amount of surgical intervention in the preoperative stage, taking into account individual degenerative changes of the FJs, the orientation of the joint surfaces and their angulation, the presence or absence of tropism for improvement of long-term postoperative clinical outcomes, minimization of postoperative instability, and the restoration of normal biomechanics for prevention of the progression of degenerate changes in lumbar segments. . $^{2,10,11}$

The specific aim of this study was to search for therapeutic and diagnostic approaches to optimize the outcomes of surgical treatment of patients with degenerative diseases of the lower lumbar spine, based on the analysis of the clinical and morphological parameters of the VMS

The overall aim of this study was to analyze the impact of the relationship between tropism and angulation of the lower lumbar facet joints on a remote clinical outcome after dynamic and rigid surgical interventions, to determine the optimal surgical tactics.

\section{METHODS}

The study was approved by the ethics committee of the Irkutsk State Medical University; each of the patients included in the study gave written informed consent - protocol No. 2 by March 13, 2013.

A total of 151 patients who underwent in-patient treatment at the Center for Neurosurgery of the Railway Clinical Hospital at the Irkutsk-Passenger Railway station of the Russian Railways in the period 2013 to 2016. Three representative groups were singled out: in 48 cases, a discectomy was performed through extraperitoneal pararectal access with implantation of the M-6 disc prosthesis (Spinal Kinetics, USA) (I group); in 42 cases - interbody fusion was performed with the T-pal cage (Synthesys, Switzerland) using the
TLIF method with the ipsilateral transpedicular stabilization by the Viper II system (Synthesys, Switzerland); contralateral fixation with the Facet Wedge implant (Synthesys, Switzerland). 1) ( $n=48)$ the use of an artificial prosthesis intervertebral disc (IVD); 2$)(n=42)$ the use of interbody fusion combined with transpedicular and transfacet stabilization; 3$)(n=51)$ the use of interbody fusion and bilateral transpedicular stabilization. Exclusion and exclusion criteria for the study were indications and contraindications for the implementation of interbody fusion to treat clinically significant pathological mobility of the vertebral-motor segments.

\section{Inclusion criteria}

Ineffective conservative therapy, prolonged or recurrent pain syndrome, persistent neurological deficit caused by the phenomena of radicular pain to sciatica with peripheral paresis;

Decrease in the height of the interbody spacing by more than $1 / 3$ of the height of the overlying;

Absence of signs of segment instability (segmental angulation > $10^{\circ}$, linear translation $>4 \mathrm{~mm}$ );

A one-level symptomatic degenerative disease of the lower lumbar spine, according to neuroimaging data

\section{Contraindications}

Central stenosis of the spinal canal;

Spondylolisthesis with or without spondylolysis;

Severe concomitant pathology;

Significant osteoporosis (decrease in BMD - by 2.8 or more according to the WHO T-criterion in 1995);

Need to correct the sagittal balance;

Need for a surgical correction of 2 or more segments of the lumbosacral spine.

Long-term clinical data were studied (the level of the pain syndrome according to the visual analogue scale (VAS) in the lumbar and lower limbs, the quality of life of the patients according to the questionnaire for patients with back pain Oswestry (ODI), satisfaction with the result of surgical treatment according to the Macnab scale, ${ }^{3}$ and instrumental parameters determined by magnetic resonance imaging (MRI) of the lumbar spine (angulation and tropism of FJs) according to the method of Karacan et al. ${ }^{12}$. (Figure 1)

Calculation of the angles of FJ was performed on axial MRI-grams, using the software RadiAnt DICOM Viewer. Tropism of FJs was verified in the presence of the difference between the values of the angles of the right and left FJs of more than $10^{\circ}$. Values of the difference in angles between FJs at the level of surgical intervention were compared with those at the level of adjacent segments (i.e., for IVD of $L_{\| 1 \mid} L_{\mid V}$, the control level was $L_{\mid V}-L_{V}$, for $L_{I V} L_{V}-L_{\| I}-L_{\mid V}$ or $L_{V} S_{1}$, and for IVD of $\left.L_{V} S_{1}-L_{\mid v}-L_{V}\right)$.

After the surgery, the follow-up catamnesis was at least 24 and a maximum of 48 months, with a median of 36 months.

To assess the significance of differences in the sample populations, the criteria of nonparametric statistics were used, and $p<0.05$ was taken as the lower limit for reliability. The data are represented by the median and interquartile range in the form of Me $(25 ; 75)$. 


\section{RESULTS}

Analysis of gender characteristics of patients. General characteristics of the studied patients by sex, age, and constitutional characteristics are shown in Table 1.

It was found that the operated patients were predominantly male (more than $70 \%)$ and overweight (BMI > 25.0).

Analysis of remote clinical outcomes. Characteristics of distant parameters (after 24 months, on average) of patients in the study groups, in terms of the level of pain, quality of life and the degree of patient satisfaction with the surgery performed, are shown in Table 2.

Analyzing the long-term outcomes of surgical treatment (on average in 24 months) of the patients with degenerative diseases of the lower lumbar segments with the use of dynamic fixation (group I), interbody fusion with transpedicular and less rigid transfacetal stabilization (group II), and interbody fusion with rigid transpedicular stabilization (group III), we obtained the minimum values for level of pain, on the visual analogue scale, good functional state, according to the ODI index, and predominantly good results on the Macnab scale of subjective satisfaction with surgical treatment outcome.

Analysis of clinical and morphological parameters of the affected vertebral-motor segments of patients, and their relationship with the outcome of surgical treatment.

The main clinical parameters that have a direct correlation with the clinical postoperative outcome and quality of life level are the degree of pain according to the VAS scale, and functional state according to the ODI index. Correlation analysis of the above clinical components and morphological characteristics - angulation and tropism of FJs according to the Karacan method was performed. Correlation dependence of the long-term outcome of surgical treatment according to VAS and ODI with the studied neuroimaging parameters is shown in Tables 3, 4.

In the analysis, it was found that the angulation index of FJs in group I was significantly correlated with the clinical parameters of VAS and ODI, the correlation dependence with the index of tropism

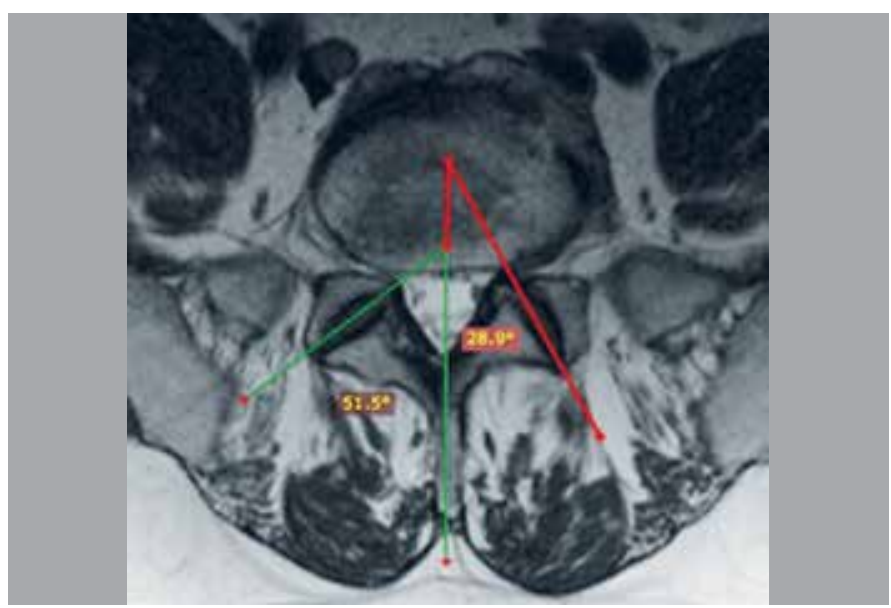

Figure 1. The procedure for calculating the angles of FJ by the method of Karacan et al. using the program RadiAnt DICOM Viewer: the angle of FJs is formed by the intersection of the lines drawn through the middle of the articular cleft of FJs and the line drawn through the center of the IVD and coinciding with the axis of the spinous process.

Table 1. The distribution of the patients by sex, age, and constitutional characteristics.

\begin{tabular}{c|c|c|c|c}
\hline \multicolumn{2}{c|}{ Criterion } & $\begin{array}{c}\text { Group I } \\
(\mathbf{n = 4 8 )}\end{array}$ & $\begin{array}{c}\text { Group II } \\
(\mathbf{n}=\mathbf{4 2})\end{array}$ & $\begin{array}{c}\text { Group III } \\
(\mathbf{n}=\mathbf{5 1})\end{array}$ \\
\hline \multicolumn{2}{c}{ age, yrs } & $37(32 ; 45)$ & $39.5(33 ; 49)$ & $40(34 ; 54)$ \\
\hline \multirow{2}{*}{ Gender } & Males, n, \% & $34(71 \%)$ & $31(74 \%)$ & $38(75 \%)$ \\
\cline { 2 - 5 } & Females, n, \% & $14(29 \%)$ & $11(26 \%)$ & $13(25 \%)$ \\
\hline \multicolumn{2}{c}{$\mathrm{BMI}, \mathrm{kg} / \mathrm{m}^{2}$} & $25.6(23.1 ; 29.6)$ & $26.1(23.3 ; 29.6)$ & $26.5(23.6 ; 29.9)$ \\
\hline
\end{tabular}

Note: BMl - body weight index.
Table 2. Distribution of the studied patients for long-term results of surgical treatment.

\begin{tabular}{|c|c|c|c|c|}
\hline \multicolumn{2}{|c|}{ Criterion } & $\begin{array}{l}\text { Group I } \\
(\mathrm{n}=48)\end{array}$ & $\begin{array}{l}\text { Group II } \\
(n=42)\end{array}$ & $\begin{array}{c}\text { Group III } \\
(n=51)\end{array}$ \\
\hline \multicolumn{2}{|c|}{ VAS, lumbar spine, $\mathrm{mm}$} & $10.5(6 ; 14)$ & $14(9 ; 24)$ & $19(10 ; 29)$ \\
\hline \multicolumn{2}{|c|}{ VAS, lower limbs, mm } & $8.5(4 ; 12)$ & $14(6 ; 22)$ & $15.5(7 ; 24)$ \\
\hline \multicolumn{2}{|c|}{ ODI, score } & $10(6 ; 16)$ & $16(8 ; 26)$ & $16(8 ; 32)$ \\
\hline \multirow{4}{*}{ Macnab } & Excellent & $25(52 \%)$ & $18(43 \%)$ & $11(21 \%)$ \\
\hline & Good & $20(42 \%)$ & $15(36 \%)$ & $27(53 \%)$ \\
\hline & Satisfactory & $3(6 \%)$ & $7(16 \%)$ & $9(18 \%)$ \\
\hline & Unsatisfactory & - & $2(5 \%)$ & $4(8 \%)$ \\
\hline
\end{tabular}

Note: VAS - Visual Analogue Scale for pain. ODI - Oswestry Disability Index. Macnab - scale of subjective evaluation of treatment outcome.

Table 3. Correlation of the FJ angulation index with remote clinical parameters by VAS and ODI and tropism index of FJ.

\begin{tabular}{c|c|c|c|c|c|c}
\hline \multirow{2}{*}{ Criterion } & \multicolumn{2}{|c|}{ Group I (n=48) } & \multicolumn{2}{c|}{ Group II (n=42) } & \multicolumn{2}{c}{ Group III (n= 51) } \\
\cline { 2 - 7 } & $\mathbf{R}$ & $\mathbf{p}$ & $\mathbf{R}$ & $\mathbf{p}$ & $\mathbf{R}$ & $\mathbf{p}$ \\
\hline $\begin{array}{c}\text { VAS, lumbar spine } \\
\text { 24 months }\end{array}$ & 0.81 & $<0.05$ & -0.91 & $<0.05$ & -0.90 & $<0.05$ \\
\hline $\begin{array}{c}\text { VAS, lower limbs, } \\
\text { 24 months }\end{array}$ & 0.79 & $<0.05$ & -0.92 & $<0.05$ & -0.89 & $<0.05$ \\
\hline ODI 24 months & 0.90 & $<0.05$ & -0.90 & $<0.05$ & -0.85 & $<0.05$ \\
\hline FJ tropism & 0.09 & $>0.05$ & 0.95 & $<0.05$ & 0.95 & $<0.05$ \\
\hline
\end{tabular}

Note: $\mathrm{R}$ - the correlation index; $\mathrm{p}$ - confidence probability.

Table 4. Correlation of tropism index of FJ with remote clinical parameters according to VAS and ODI and FJ angulation index

\begin{tabular}{c|c|c|c|c|c|c}
\hline \multirow{2}{*}{ Criterion } & \multicolumn{2}{|c|}{ Group I (n=48) } & \multicolumn{2}{|c|}{ Group II $(\mathbf{n}=\mathbf{4 2})$} & Group III (n= 51) \\
\cline { 2 - 7 } & $\mathbf{R}$ & $\mathbf{p}$ & $\mathbf{R}$ & $\mathbf{p}$ & $\mathbf{R}$ & $\mathbf{p}$ \\
\hline $\begin{array}{c}\text { VAS, lumbar spine } \\
\text { 24 months }\end{array}$ & -0.44 & $>0.05$ & -0.98 & $<0.05$ & -0.99 & $<0.05$ \\
\hline $\begin{array}{c}\text { VAS, lower limbs, } \\
\text { 24 months }\end{array}$ & -0.45 & $>0.05$ & -0.97 & $<0.05$ & -0.97 & $<0.05$ \\
\hline ODI 24 months & -0.18 & $>0.05$ & -0.97 & $<0.05$ & -0.95 & $<0.05$ \\
\hline FJ angulation & 0.04 & $>0.05$ & 0.95 & $<0.05$ & 0.95 & $<0.05$ \\
\hline
\end{tabular}

Note: $\mathrm{R}$ - correlation index; $\mathrm{p}$ - confidence probability.

was absent; in group II and III, an inverse correlation was observed with all the parameters studied, except for the tropism of FJs, where a direct significant correlation was verified.

In the analysis, it was found that the index of tropism of FJs in group I did not significantly correlate with the studied parameters; in groups || and III, an inverse correlation was observed with all the clinical parameters studied, and a significant inverse correlation with tropism of FJs.

Thus, the value of FJ angulation and, in some cases, the significance of the tropism of FJs, determined by the MRI method, have a direct impact on long-term clinical outcomes, which, perhaps, makes it possible to determine the possible tactics of surgical treatment. Postoperative outcomes were categorized as follows:

"good": a complete or near complete return to the former level of social and physical activity (before the onset of the disease or the last exacerbation) (possible limitation of major physical activity); "unsatisfactory": household and social activity is not fully restored, no effect from the surgery or deterioration of the state.

A comparison of the clinical and instrumental data of patients in the study groups is presented in Table 5 .

Taking into account the degree of the impact of the investigated instrumental parameters on the remote clinical outcome for optimization of treatment tactics for patients with degenerative diseases of the lower lumbar spine, it was determined that:

In the group of patients operated according to the dynamic fixation method, minimum VAS and ODI scores and a smaller degree of degenerative changes in the adjacent segment were achieved with preoperative parameters of FJs: angulation $<60^{\circ}$, regardless of the presence of tropism. (Figure 2)

In the group of patients operated by the method of rigid stabilization, minimum VAS and ODI scores and a smaller degree of 
Table 5. Comparative analysis of clinical data depending on the postoperative outcome in patients of the study groups.

\begin{tabular}{|c|c|c|c|c|c|c|c|c|c|}
\hline Criterion & \multicolumn{2}{|c|}{ Group I $(n=48)$} & p & \multicolumn{2}{|c|}{ Group II $(n=42)$} & p & \multicolumn{2}{|c|}{ Group III $(n=51)$} & p \\
\hline ODI, 24 months score & $6(6 ; 8)$ & $16(16 ; 18)$ & $<0.01$ & $8(6 ; 8)$ & $26(20 ; 28)$ & $<0.01$ & $8(8 ; 10)$ & $32(28 ; 36)$ & $<0.01$ \\
\hline VAS, lumbar spine 24 months, mm & $6(5 ; 8)$ & $14(14 ; 16)$ & $<0.01$ & $9(8 ; 10)$ & $24(22 ; 26)$ & $<0.01$ & $10(10 ; 12)$ & $29(27 ; 30)$ & $<0.01$ \\
\hline FJ angulation before surgery, degree & $50(44 ; 59)$ & $69(62 ; 74)$ & $<0.01$ & $70(62 ; 78)$ & $52(48 ; 56)$ & $<0.01$ & $69(61 ; 82)$ & $52(49 ; 56)$ & $<0.01$ \\
\hline FJ tropism before surgery & $+/$ & $+/-$ & $>0.05$ & + & $+/-$ & $<0.01$ & - & $+/-$ & $<0.01$ \\
\hline General lordosis before surgery & $31(27 ; 37)$ & $30(25 ; 39)$ & $>0.05$ & $34(27 ; 36)$ & $32(24 ; 37)$ & $>0.05$ & $30(24 ; 37)$ & $31(23 ; 37)$ & $>0.05$ \\
\hline General lordosis after surgery & $55(46 ; 62)$ & $33(31 ; 37)$ & $<0.01$ & $53(42 ; 68)$ & $37(31 ; 37)$ & $<0.01$ & $52(44 ; 67)$ & $37(35 ; 39)$ & $<0.01$ \\
\hline
\end{tabular}
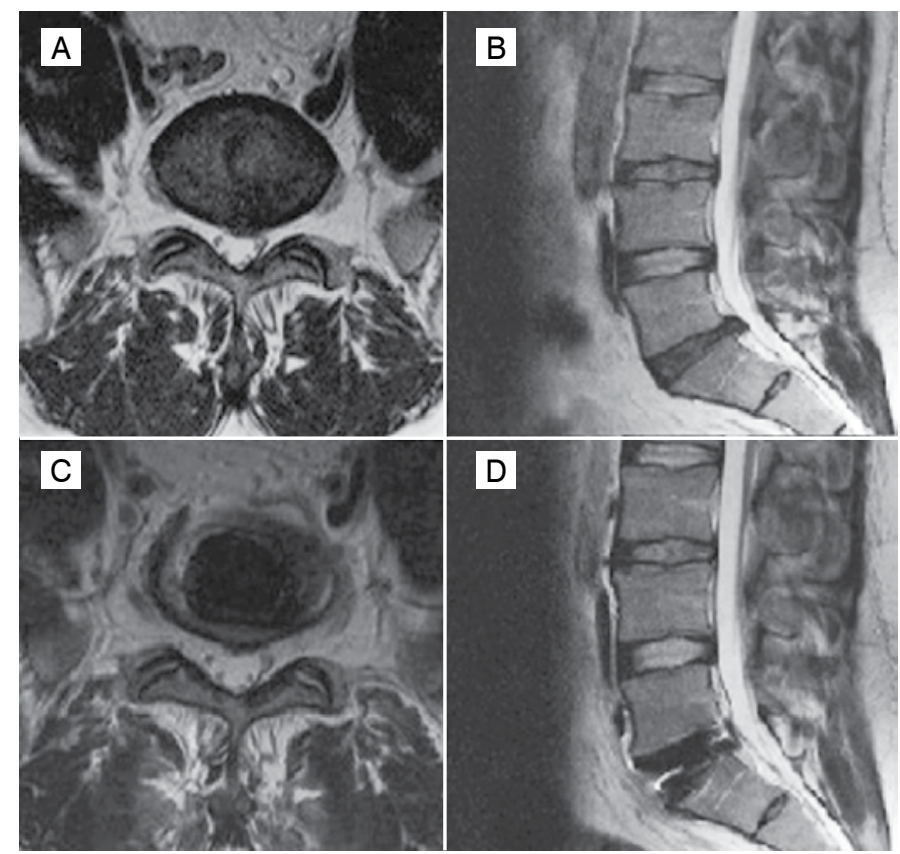

Figure 2. Patient A., 34 years old. MRI of the lumbosacral spine, T2 weighted images: A - axial projection: angulation of FJs - 58 , no tropism; B - sagittal projection (arrow indicates Hernia of IVD $\left.L_{-} S_{1}\right)$; D - axial projection after surgery - total arthroplasty of $\mathrm{L}_{-} \mathrm{S}_{\text {}}$ with artificial prosthesis IVD M6; $\mathrm{C}$ - sagittal projection after surgery. The level of pain in the lumbar spine according to VAS before surgery was $82 \mathrm{~mm}$, in the left lower limb - $86 \mathrm{~mm}$, ODI - 64 scores. The level of pain in the lumbar spine according to VAS in 24 months after the surgery was $6 \mathrm{~mm}$, in the left lower limb VAS was $2 \mathrm{~mm}$, ODI -8 scores.

degenerative changes in the adjacent segment were achieved with preoperative parameters of FJs: angulation $>60^{\circ}$, while in the absence of FJ tropism, a contralateral transfacetal fixation is possible (Figure 3), and in the presence of tropism, it is advisable to perform bilateral transpedicular stabilization. (Figure 4)

\section{DISCUSSION}

Currently, approaches to surgical treatment of patients with different degrees of degenerative diseases of FJs are not well defined. ${ }^{2,3}$ Various surgical interventions for degenerative FJ diseases are performed in spinal surgery, ranging from minimally invasive puncture techniques to partial or total facetectomy with rigid stabilization, with ambiguous results. ${ }^{1,13,14}$ This is primarily due to the lack of objective indications for choosing the type of surgical treatment, and a failure
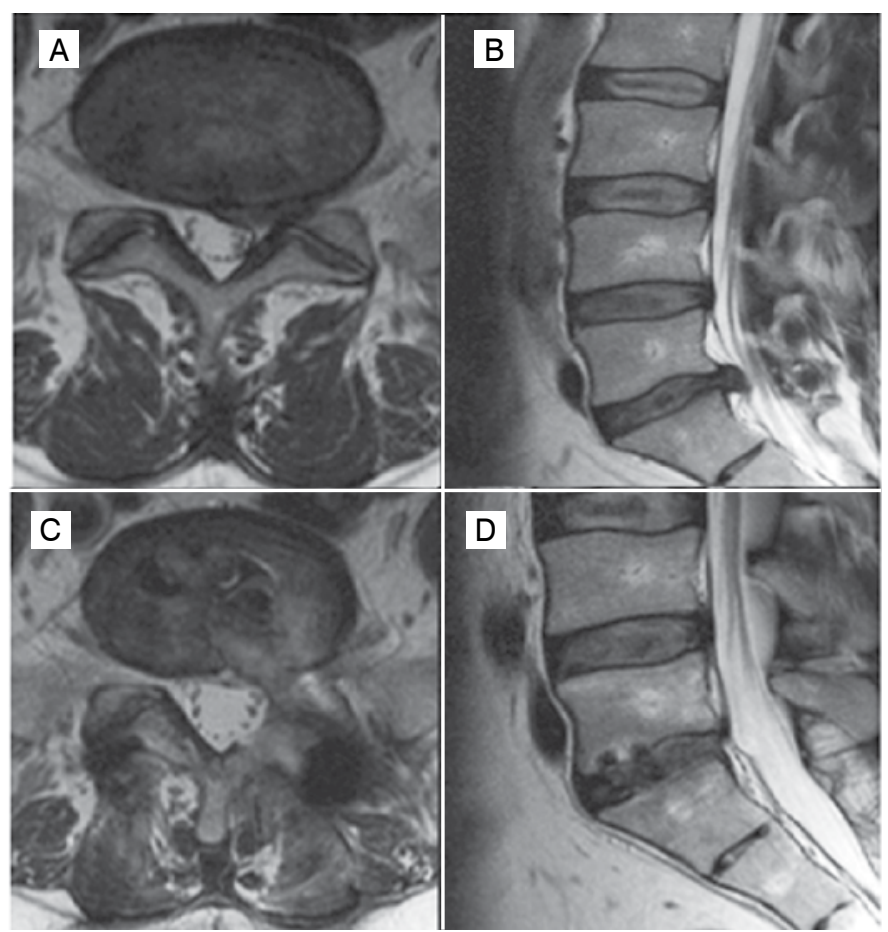

Figure 3. Patient G., 39 years old. MRI of the lumbosacral spine, T2 weighted images: A - axial projection: angulation of $\mathrm{FJ}-63^{\circ}$, no tropism; B - sagittal projection (arrow indicates Hernia of IVD $L_{-} S_{1}$ ); C - axial projection after surgery in the volume of microsurgical discectomy $L_{r} S_{1}$, interbody fusion $L_{-} S_{1}$. transpedicular fixation $L_{-} S_{1}$ by the system of cannulated screws on the left, contralateral transfacetal fixation by Facet Wedge system on the right; $D$ - sagittal projection after surgery. The level of pain in the lumbar spine according to VAS before surgery was $77 \mathrm{~mm}$, in the left lower limb - $81 \mathrm{~mm}, \mathrm{ODI}-62$ scores. The level of pain in the lumbar spine according to VAS in 24 months after the surgery was $6 \mathrm{~mm}$, in the left lower limb - $4 \mathrm{~mm}$, ODI - 4 scores.

to take into account the individual anatomical features of FJs. ${ }^{2,3}$

With minimum degenerative changes of FJs - I-II degree according to the classification of Fujiwara A., ${ }^{2}$ conservative treatment is used, which is analogous to the therapeutic principle that osteoarthritis in any location consists in the use of non-steroidal anti-inflammatory drugs, hormonal anti-inflammatory therapy, drugs-chondroprotectors, and physiotherapy. ${ }^{11}$ Minimally-invasive methods of treatment include the use of paravertebral blockades, radiofrequency, laser, chemodenervation of FJs, and puncture of FJs with the use of a synovial fluid prosthesis (facetoplasty). ${ }^{2,3,10}$ 


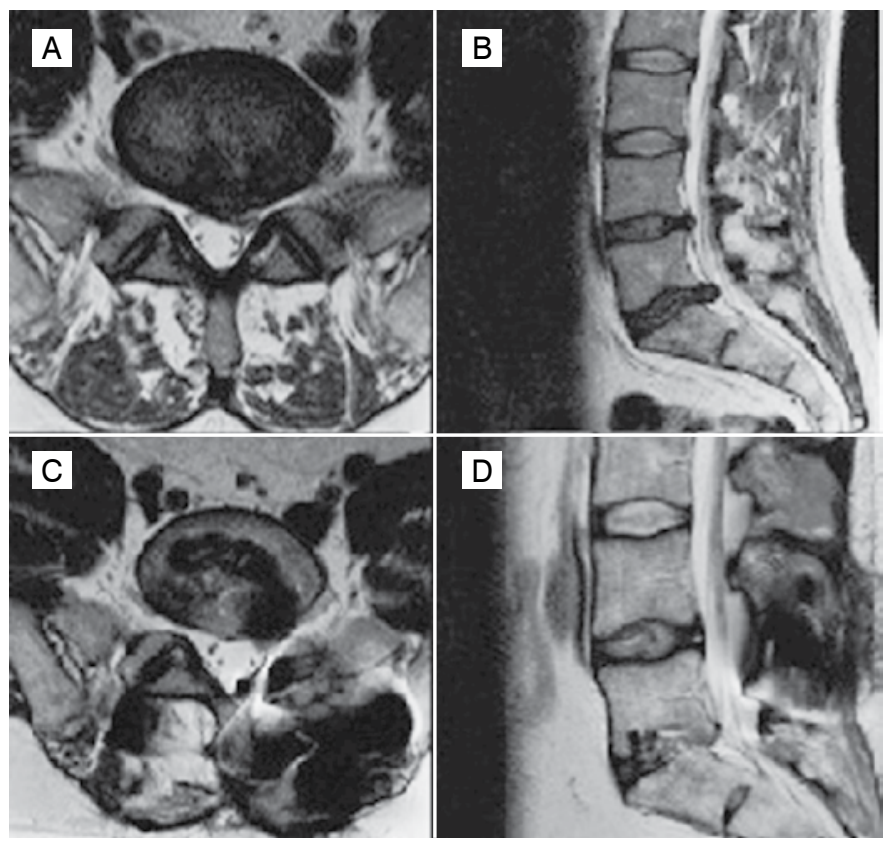

Figure 4. Patient P., 39 years old. MRI of the lumbosacral spine, T2 weighted images: a - axial projection: angulation of $\mathrm{FJ}$ - $65^{\circ}$, tropism is present; $\mathrm{b}$ - sagittal projection (arrow indicates Hernia of IVD $L_{-} S_{1}$ ); $c$ - axial projection after surgery in the volume of microsurgical discectomy $L_{-} S_{1}$, interbody fusion $L_{-} S_{1}$., transpedicular fixation $\mathrm{L}_{\checkmark} \mathrm{S}_{\text {| }}$ by the system of cannulated screws; $d$ - sagittal projection after surgery. The level of pain in the lumbar spine according to VAS before surgery was $78 \mathrm{~mm}$, and in the left lower limb, $72 \mathrm{~mm}$, ODI - 62 scores. The level of pain in the lumbar spine according to VAS in 24 months after the surgery was $4 \mathrm{~mm}$, and in the left lower limb, $3 \mathrm{~mm}$, ODI - 8 scores.

With significant degenerative changes in FJs and the ineffectiveness of conservative treatment, a radical method of treatment is used - facetectomy followed by instrumental fixation of VMS. ${ }^{2,4}$

The accumulated experience of the adverse consequences of the use of interbody fusion and transpedicular stabilization contributes to the detailing of postoperative complications and the development of measures aimed at preventing their development. ${ }^{15}$

One of the most common complications of rigid fixation is degeneration of the adjacent segment, which is between 12 and $37 \%$, often requiring revision surgery. ${ }^{10,16-18}$

In a number of cases, the development of postoperative pain syndrome is associated with impulse from the nociceptors of the IVD, which is caused by an increased load on the closure plates after the implantation of the cage, which is significantly higher than in the unchanged IVD. ${ }^{19,20}$

A good clinical outcome after rigid stabilization is $15-95 \%$ (with an average of $68 \%$ ). ${ }^{16-21}$ Gibson et al. found that $32 \%$ of cases in the late postoperative period developed pseudoarthrosis, accompanied by unsatisfactory clinical outcomes and instrumental signs of pathological mobility. ${ }^{21}$ In addition, Gibson et al. showed that the high frequency of bone block formation is not correlated with long-term clinical outcomes. ${ }^{22}$
Unsatisfactory long-term clinical outcomes associated with the development of the syndrome of the adjacent segment, postoperative instability, pseudoarthrosis and scar intracanal changes have prompted researchers to search for the key factors that cause their development. Thus, many studies have confirmed the impact of angulation and tropism of FJs on the biomechanics of the spinal column. ${ }^{23-25}$ However, no correlation has been made with the remote clinical outcomes of these neuroimaging parameters.

Many authors testify to the impact of tropism and angulation of FJs on the development of IVD degeneration. ${ }^{23-25}$ However, to our knowledge, there is no study to date on the possible correlation of these morphometric parameters with a remote clinical outcome.

For the first time, Farfan $\mathrm{H}$. et al. revealed a significant correlation between tropism of FJs and the formation of IVD hernias in the lumbosacral spine. ${ }^{24}$ Also, the authors point out that the hernias of the lumbar IVD appear on the side of FJs with the smallest angle, since with this orientation of FJs, it is not capable of reducing torsion loads affecting on the fibrous ring during movement. ${ }^{16,25}$

Clinical studies are currently underway to investigate the relationship between tropism and the orientation of FJs with the onset of degenerative spondylolisthesis. ${ }^{23,25}$

Boden S. et al. ${ }^{26}$ studied FJ angulations on MRI images from 140 patients and found that a more sagittal location and tropism of FJs contribute to the formation of degenerative spondylolisthesis.

Cinotti G. et al. according to CT data of 54 patients revealed a significant correlation between asymmetric of FJs and degenerative spondylolisthesis at the level of $L_{\mid V} L_{V}, L_{V} S_{\mid}{ }^{27}$

Thus, the parameters of angulation and tropism of FJ can serve as objective criteria for a possible choice of surgical tactics, and for predicting a remote postoperative clinical outcome in patients with degenerative diseases of the lower lumbar VMS.

\section{CONCLUSIONS}

A comprehensive clinical and instrumental examination including lumbar spondylography, magnetic resonance imaging for objective analysis of morphostructural changes in the VMS is recommended for all patients with degenerative diseases of the lower lumbar spine.

The use of angulation and tropism parameters of FJs, which are determined by a non-invasive MRI method, enable the degree of degeneration of the anterior (IVD) and posterior (FJ) support complexes of the lower lumbar segments to be established, and possible tactics determined.

In the presence of neuroimaging parameters of angulation of FJs less than $60^{\circ}$, regardless of the presence of tropism, it is possible to perform total arthroplasty of IVD.

When detecting neuroimaging parameters of FJs angulation more than $60^{\circ}$, rigid stabilization of the operated segment is recommended, while in the absence of FJs tropism, a contralateral transfacetal fixation is possible; in the presence of tropism, it is expedient to perform bilateral transpedicular stabilization.

All authors declare no potential conflict of interest related to this article.

CONTRIBUTION OF THE AUTHORS: Each author made significant individual contributions to this manuscript. VAB (0000-0003-4349-7101)* were the main contributors in the drafting of the manuscript. AAK (0000-0001-9039-9147)*, AKO (0000-0003-1556-3095) ${ }^{\star}$, and YYP (0000-0003-2633$7149)^{\star}$ performed the surgery, followed up patients and gathered clinical data. AKO evaluated the data from the statistical analysis. YYP, AAK and VAB performed the literature search and review of the manuscript, and contributed to the intellectual concept of the study. IVB (0000-0003-3549-0794)* ${ }^{\star}$ ORCID (Open Researcher and Contributor ID)

\section{REFERENCES}

1. Kalichman L, Kim DH, Li L, Guermazi A, Hunter DJ. Computed tomography-evaluated features of spinal degeneration: prevalence, intercorrelation, and association with self-reported low back pain. Spine J. 2010;10(3):200-8.

2. Issack PS, Cunningham ME, Pumberger M, Hughes AP, Cammisa FP Jr. Degene- rative lumbar spinal stenosis: evaluation and management. J Am Acad Orthop Surg. 2012;20(8):527-35.

3. Turner JA, Ersek M, Herron L, Haselkorn J, Kent D, Ciol MA, et al. Patient outcomes after lumbar spinal fusions. JAMA. 1992;268(7):907-11. 
4. Adogwa O, Parker SL, Shau DN, Mendenhall SK, Aaronson OS, Cheng JS, et al. Preoperative Zung depression scale predicts outcome after revision lumbar surgery for adjacent segment disease, recurrent stenosis, and pseudarthrosis. Spine J. 2012: 12(3):179-85.

5. Arts MP, Kols NI, Onderwater SM, Peul WC. Clinical outcome of instrumented fusion for the treatment of failed back surgery syndrome: a case series of 100 patients. Acta Neurochir (Wien). 2012:154(7):1213-7.

6. Byvaltsev VA, Kalinin AA, Belykh EG, Sorokovikov VA, Shepelev VV. [Optimization of segmental lumbar spine instability treatment using minimally invasive spinal fusion technique]. Zh Vopr Neirokhir Im N N Burdenko. 2015; 79(3):45-54.

7. Kalinin AA, Byvaltsev VA. Relationship between vertebral metric parameters and ou tcome of surgical treatment of degenerative spondylolisthesis with multilevel lumbar intervertebral disc lesions. Hirurgiâ pozvono nika. 2015;12(4):56-62. (In Russ.)

8. Lurie JD, Tosteson TD, Tosteson A, Abdu WA, Zhao W, Morgan TS, et al. Long-term outcomes of lumbar spinal stenosis: eight-year results of the Spine Patient Outcomes Research Trial (SPORT). Spine (Phila Pa 1976). 2015;40(2):63-76.

9. Atlas SJ, Keller RB, Wu YA, Deyo RA, Singer DE. Long-term outcomes of surgical and nonsurgical management of lumbar spinal stenosis: 8 to 10 year results from the maine lumbar spine study. Spine (Phila Pa 1976). 2005;30(8):936-43.

10. Mannion AF, Denzler R, Dvorak J, Grob D. Five-year outcome of surgical decompression of the lumbar spine without fusion. Eur Spine J. 2010:19(11):1883-91.

11. Weinstein JN, Tosteson TD, Lurie JD, Tosteson A, Blood E, Herkowitz H, et al. Surgical versus nonoperative treatment for lumbar spinal stenosis four-year results of the Spine Patient Outcomes Research Trial. Spine (Phila Pa 1976). 2010:35(14):1329-38.

12. Adogwa O, Carr K, Fatemi P,VerlaT, Gazcon G, Gottfried O,et al. Psychosocial factors and surgical outcomes: are elderly depressed patients less satisfied with surgery? Spine (Phila Pa 1976). 2014:39(19):1614-9.

13. Sinikallio S, Aalto T, Airaksinen O, Lehto SM, Kröger H, Viinamäki H. Depression is associated with a poorer outcome of lumbar spinal stenosis surgery: a two-year prospective follow-up study. Spine (Phila Pa 1976). 2011;36(8):677-82.

14. D'Angelo C, Mirijello A, Ferrulli A, Leggio L, Berardi A, Icolaro N, et al. Role of trait anxiety in persistent radicular pain after surgery for lumbar disc herniation: a 1-year longitudinal study. Neurosurgery. 2010;67(2):265-71.

15. Pakarinen M, Vanhanen S, Sinikallio S, Aalto T, Lehto SM, Airaksinen O, et al. Depressive burden is associated with a poorer surgical outcome among lumbar spinal stenosis patients: a 5-year follow-up study. Spine J. 2014;14(10):2392-6.

16. Miller JA, Derakhshan A, Lubelski D, Alvin MD, McGirt MJ, Benzel EC, et al. The impact of preoperative depression on quality of life outcomes after lumbar surgery. Spine J. 2015;15(1):58-64.

17. Nechanicka N, Barsa P, Harsa P. Psychosocial Factors in Patients Indicated for Lumbar Spinal Stenosis Surgery. J Neurol Surg A Cent Eur Neurosurg. 2016;77(5):432-40.

18. Maratos EC, Trivedi R, Richards H, Seeley H, Laing RJ. Psychological distress does not compromise outcome in spinal surgery. Br J Neurosurg. 2012;26(4):466-71.

19. Archer KR, Seebach CL, Mathis SL, Riley LH 3rd, Wegener ST. Early postoperative fear of movement predicts pain, disability, and physical health six months after spinal surgery for degenerative conditions. Spine J. 2014;14(5):759-67.

20. Mannion AF, Elfering A, Staerkle R, Junge A, Grob D, Dvorak J, et al. Predictors of multidimensional outcome after spinal surgery. Eur Spine J. 2007; 16(6):777-86.

21. Seebach CL, Kirkhart M, Lating JM, Wegener ST, Song Y, Riley LH 3rd, et al. Examining the role of positive and negative affect in recovery from spine surgery. Pain. 2012:153(3):518-25

22. Anderson JT, Haas AR, Percy R, Woods ST, Ahn UM, Ahn NU. Clinical depression is a strong predictor of poor lumbar fusion outcomes among workers' compensation subjects. Spine (Phila Pa 1976). 2015;40(10):748-56.

23. Adogwa O, Parker SL, Shau DN, Mendenhall SK, Bydon A, Cheng JS, et al. Preoperative Zung depression scale predicts patient satisfaction independent of the extent of improvement after revision lumbar surgery. Spine J. 2013;13(5):501-6.

24. Murphy HA, Warnick E, McGintee R, Nicholson K, Hollern DA, Stawicki C, et al. Which Domains of the ODI Best Predict Change in Physical Function in Patients after Surgery for Degenerative Lumbar Spondylolisthesis? Spine (Phila Pa 1976). 2017.

25. Havakeshian S, Mannion AF. Negative beliefs and psychological disturbance in spine surgery patients: a cause or consequence of a poor treatment outcome? Eur Spine J. 2013;22(12):2827-35.
26. Roitberg BZ, Thaci B, Auffinger B, Kaplan L, Shen J, Brown FD, et al. Comparison between patient and surgeon perception of degenerative spine disease outcomes-a prospective blinded database study. Acta Neurochir (Wien). 2013;155(5):757-64.

27. Urban-Baeza A, Zárate-Kalfópulos B, Romero-Vargas S, Obil-Chavarría C, Brenes-Rojas L, Reyes-Sánchez A. Influence of depression symptoms on patient expectations and clinical outcomes in the surgical management of spinal stenosis. $J$ Neurosurg Spine. 2015;22(1):75-9.

28. Djurasovic M, Glassman SD, Dimar JR 2nd, Crawford CH 3rd, Bratcher KR, Carreon LY Changes in the Oswestry Disability Index that predict improvement after lumbar fusion. J Neurosurg Spine. 2012;17(5):486-90.

29. Adogwa O, Elsamadicy AA, Han JL, Cheng J, Karikari I, Bagley CA. Do measures of surgical effectiveness at 1 year after lumbar spine surgery accurately predict 2-year outcomes? J Neurosurg Spine. 2016;25(6):689-96.

30. Chaichana KL, Mukherjee D, Adogwa O, Cheng JS, McGirt MJ. Correlation of preoperative depression and somatic perception scales with postoperative disability and quality of life after lumbar discectomy. J Neurosurg Spine. 2011;14(2):261-7.

31. Misterska $E$, Jankowski R, Głowacki M. Psychometric properties of the Polish language version of the chronic pain coping inventory-42 for patients treated surgically due to herniated lumbar discs and spondylotic changes. Med Sci Monit. 2014;20:789-801.

32. Benaim C, Léger B, Vuistiner P, Luthi F. Validation of the French Version of the "Patterns of Activity Measure" in Patients with Chronic Musculoskeletal Pain. Pain Res Manag. 2017;2017:6570394.

33. Kovacs FM, Seco J, Royuela A, Peña A, Muriel A. Research The correlation between pain, catastrophizing, and disability in subacute and chronic low back pain: a study in the routine clinical practice of the Spanish National Health Service. Spine (Phila Pa 1976). 2011:36(4):339-45

34. Cho S, Kim HY, Lee JH. Validation of the Korean version of the Pain Catastrophizing Scale in patients with chronic non-cancer pain. Qual Life Res. 2013; 22(7):1767-72.

35. Heneweer $H$, van Woudenberg NJ, van Genderen F, Vanhees L, Wittink H. Measuring psychosocial variables in patients with (sub) acute low back pain complaints, at risk for chronicity: a validation study of the Acute Low Back Pain Screening Questionnaire-Dutch Language Version. Spine (Phila Pa 1976). 2010:35(4):447-52.

36. Versteegh MM, Leunis A, Uyl-de Groot CA, Stolk EA. Condition-specific preference-based measures: benefit or burden? Value Health. 2012;15(3):504-13.

37. Misterska E, Jankowski R, Głowacki M. Chronic pain coping styles in patients with herniated lumbar discs and coexisting spondylotic changes treated surgically: Considering clinical pain characteristics, degenerative changes, disability, mood disturbances, and beliefs about pain control. Med Sci Monit. 2013; 19:1211-20.

38. Kim C, Harris JA, Muzumdar A, Khalil S, Sclafani JA, Raiszadeh K, et al. The effect of anterior longitudinal ligament resection on lordosis correction during minimally invasive lateral lumbar interbody fusion: Biomechanical and radiographic feasibility of an integrated spacer/plate interbody reconstruction device. Clin Biomech (Bristol, Avon). 2017;43:102-108.

39. Chotai S, Devin CJ, Archer KR, Bydon M, McGirt MJ, Nian H, et al. Effect of patients' functional status on satisfaction with outcomes 12 months after elective spine surgery for lumbar degenerative disease. Spine J. 2017; 17(12):1783-93.

40. Johansson AC, Linton SJ, Rosenblad A, Bergkvist L, Nilsson O. A prospective study of cognitive behavioural factors as predictors of pain, disability and quality of life one year after lumbar disc surgery. Disabil Rehabil. 2010;32(7):521-9.

41. Archer KR, Devin CJ, Vanston SW, Koyama T, Phillips SE, George SZ, et al. Cognitive-Behavioral-Based Physical Therapy for Patients With Chronic Pain Undergoing Lumbar Spine Surgery: A Randomized Controlled Trial. J Pain. 2016;17(1):76-89.

42. Chapman JR, Norvell DC, Hermsmeyer JT, Bransford RJ, DeVine J, McGirt MJ, et al Evaluating common outcomes for measuring treatment success for chronic low back pain. Spine (Phila Pa 1976). 2011;36(21 Suppl):S54-68.

43. Donk RD, Verbeek ALM, Verhagen WIM, Groenewoud H, Hosman ATF, Bartels RHMA Substantial clinical benefit for Neck Disability Index revisited: establishing the goal for treatment? Eur Spine J. 2018;27(6):1262-65. 